\title{
0 podstawowych związkach prawa i diagnostyki edukacyjnej
}

\begin{abstract}
General legal position of an individual in terms of education is shaped by the norms of constitutional weight. Among them a special place is taken up by the principle of equal access to education, which is one of the guarantees of the right to education. In the author's opinion, the above mentioned principle has a close relation to educational diagnostics, especially its normalized part, which is didactic measurement. Therefore, an extralegal element, which is the measurement (of its quality), has a significant influence on the legal position of an individual and determines the possibility to use one of the most fundamental rights. From the pedagogical perspective, the author proposes taking into account the legal environment in which educational diagnostics functions, and which - although roughly - he presents in the article, whereas from the legal perspective he points out to the necessity of taking into account the educational diagnostics' conditioning in the evaluation process of implementing equal access to education.
\end{abstract}

\section{Keywords:}

educational diagnostics, didactic measurement, law, the right to education, equal access to education

1 Łukasz Kierznowski, Katedra Prawa Administracyjnego, Wydział Prawa, Uniwersytet w Białymstoku, Polska, lukasz.kierznowski@uwb.edu.pl. 
Teoria diagnostyki edukacyjnej stanowi w ostatnich latach coraz częstszy przedmiot zainteresowania przedstawicieli nauk pedagogicznych. Badania naukowe w tym obszarze są prowadzone zarówno w sposób indywidualny, jak i instytucjonalny. Jako przykład wystarczy przywołać działalność Instytutu Badań Edukacyjnych, Polskiego Towarzystwa Diagnostyki Edukacyjnej czy też, przewidziany w art. 9a ust. 2 pkt 8 ustawy z dnia 7 września 1991 r. o systemie oświaty (Dz. U. nr 95, poz. 425 z późn. zm.), obowiązek inicjowania i organizowania badań i analiz w zakresie egzaminowania przez Centralną Komisję Edukacyjną. Polska literatura w tym obszarze nie jest już zatem tak uboga, jak było to jeszcze na początku lat 90., gdy diagnostyka edukacyjna pozostawała we wstępnej fazie rozwoju (Niemierko, 1994, s. 25), co jednak nie zmienia faktu, że dyscyplina ta nadal jest uznawana za młodą (Niemierko, 2009, s. 28). O stopniowym wzroście jej znaczenia świadczy także fakt, że zagadnieniom z zakresu diagnostyki edukacyjnej poświęca się poszczególne numery czasopism naukowych z zakresu nauk pedagogicznych (zob. np. Kwartalnik Pedagogiczny, 4, 2015).

Na standardy diagnostyki edukacyjnej warto patrzeć szerzej, niż czyniono to w ostatnich dekadach. Istotne wydaje się spojrzenie na diagnostykę przez pryzmat innych dyscyplin nauki, w tym nauk prawnych, starając się niejako uchwycić istotę diagnostyki jako pewnego (specyficznego, jeśli patrzeć z perspektywy prawa) kompleksu działań organów państwa wobec jednostki i wkomponować ją w obowiązujące ramy (uwarunkowania) prawne i zasady prawa. Takie spojrzenie nie było do tej pory obecne w polskiej literaturze naukowej - zarówno z zakresu nauk pedagogicznych, jak i z zakresu nauk prawnych. W badaniach nad diagnostyką edukacyjną, jak zresztą w przypadku wielu innych obszarów nauki, dominuje podejście monodyscyplinarne. Podobnie w literaturze prawniczej dotyczącej prawa oświatowego i prawa szkolnictwa wyższego dominuje klasyczne podejście dogmatyczne, którego efektem jest tradycyjna analiza norm prawnych i ich stosowania w praktyce w ujęciu ustrojowym, materialnym oraz procesowym. Istotny jest ponadto fakt, że edukacyjna działalność władz publicznych nie pozostaje głównym przedmiotem zainteresowania przedstawicieli nauk prawnych, także tych, którzy zajmują się prawem publicznym. W tej bowiem dziedzinie zdarza się, że mamy do czynienia z zagadnieniami w ogóle nieopisanymi, a ponadto nieobecnymi w orzecznictwie sądowym, co na gruncie nauk prawnych jest sytuacją stosunkowo rzadką. Problem ten koresponduje w pewnym zakresie z innym. Jest nim niedobór prawników specjalizujących się w prawie oświatowym, który swe negatywne skutki przynosi zarówno na etapie stanowienia prawa - co przekłada się na sygnalizowaną wielokrotnie wyjątkowo niską jakość oraz skrajnie dużą niestabilność przepisów z tej dziedziny prawa (Kurzyna-Chmiel, 2012) - jak 
i stosowania prawa. Trudno zatem oczekiwać badań interdyscyplinarnych tam, gdzie istnieje niedostatek badań monodyscyplinarnych, który dodatkowo przynosi negatywne skutki także w praktyce stanowienia i stosowania prawa.

W tych uwarunkowaniach naukowych jako punkt wyjścia dla rozważań będących przedmiotem niniejszego artykułu trzeba przyjąć prawny charakter edukacji jako zorganizowanej, ciągłej działalności organów władzy publicznej skierowanej do jednostek. Jak stwierdza się w literaturze, edukacja jest częścią administracji, podobnie jak prawo oświatowe jest częścią prawa administracyjnego. Oświatą nazywa się zespół podmiotów, instytucji, zadań oraz reguł służących wykonywaniu funkcji państwa, polegającej na udostępnieniu narzędzi prawnych, ekonomicznych i społecznych, niezbędnych do uzyskania i przekazania wiedzy objętej systemem edukacji na określonych szczeblach. Z kolei wewnętrzne powiązania jednostek w ramach oświaty tworzą zwarty i jednolity system. W skład tego systemu w aspekcie podmiotowym wchodzą jednostki organizacyjne ogólne i wyspecjalizowane, za pomocą których wykonywane są zadania z zakresu edukacji. Oświatę w takim ujęciu charakteryzują m.in.: hierarchiczne podporządkowanie poszczególnych podmiotów w ramach systemu, wzajemne zależności, możliwość wydawania aktów prawnych wiążących poszczególne ogniwa systemu, wydawanie poleceń służbowych oraz przekazywanie zadań (Woźniak, 2013).

Stosunek prawny, jaki powstaje pomiędzy jednostką a organami państwa w toku pobierania przez jednostkę edukacji, jest więc stosunkiem administracyjnoprawnym. Zadania publiczne w dziedzinie oświaty należą do sfery prawa publicznego i przynależnej do niej sfery działalności świadczącej, tzn. zapewniającej dostarczanie określonych usług o charakterze społecznym na rzecz zbiorowości (Kurzyna-Chmiel, 2013). Innymi słowy powyższe sfery stanowią administracyjną działalność państwa, którym to działaniom jednostka jest - co do zasady - podporządkowana. Jednostka, korzystając z edukacji (lub będąc do tego przymuszona), zostaje wtłoczona w ramy stosunku administracyjnoprawnego, korzysta z praw i podlega obowiązkom przewidzianym w normach prawa administracyjnego (a więc jednej z części prawa publicznego), a w pewnym zakresie także w normach innych gałęzi prawa. Podlega również tzw. władztwu zakładowemu. Z kolei sposób realizacji (konkretyzacji) tych praw i obowiązków regulują przepisy proceduralne. Publicznoprawny charakter takiego stosunku pomiędzy jednostką a państwem nie jest modyfikowany nawet wtedy, gdy jednostka korzysta ze szkolnictwa niepublicznego, z tą tylko różnicą, że wówczas stosunek administracyjnoprawny istnieje równolegle ze stosunkiem cywilnoprawnym (Pierzchała, 2016).

Obowiązki organów państwa w sferze edukacji, tak jak w każdej innej sferze, w której władza publiczna wpływa na pozycję prawną jednostki, muszą mieć 
i mają swoje bezpośrednie umocowanie prawne. W przypadku większości państw najbardziej doniosłe zasady dotyczące roli państwa w edukacji uregulowane są w akcie prawnym o najwyższej mocy - konstytucji. Standardem jest np. regulowanie na poziomie konstytucyjnym prawa do nauki jako jednego z praw człowieka czy też obowiązku nauki i obowiązku szkolnego, co jest zresztą w pełni uzasadnione, zważywszy, że powyższe obowiązki publicznoprawne niezwykle głęboko ingerują w wolność jednostki. Standard ten występuje również w przypadku regulacji prawa do nauki w aktach prawa międzynarodowego (Kierznowski, 2017). Ponadto w konstytucjach wielu państw formułuje się tzw. ideały oświaty lub wzorce człowieka i obywatela, których przekazanie i wpojenie uczniom powinno być celem szkół (Czarny, 2009).

\section{ZASADA RÓWNEGO DOSTĘPU DO WYKSZTAŁCENIA JAKO JEDNA Z GWARANCJI PRAWA DO NAUKI}

W polskiej Konstytucji regulacja sfery edukacji przybiera rozbudowaną oraz specyficzną postać. Składa się na nią przewidziane w Konstytucji i przysługujące każdemu prawo do nauki, które to prawo jest dodatkowo obudowane innymi normami w doktrynie prawa konstytucyjnego i administracyjnego, a także w orzecznictwie Trybunału Konstytucyjnego, nazywanymi „gwarancjami” tego prawa (Jarosz-Żukowska, Żukowski, 2014). Jest to konstrukcja dość wyjątkowa na tle pozostałych praw drugiej generacji przewidzianych w polskiej Konstytucji; rzadko stwierdza się to wprost, ale jest to sposób konstrukcji publicznego prawa podmiotowego charakterystyczny dla konstytucji państw socjalistycznych (Skotnicki, 1995, s. 139) i nietypowy, jeśli porównać legislacyjną konstrukcję prawa do nauki z pozostałymi prawami drugiej generacji uregulowanymi w Konstytucji. Z drugiej jednak strony tak szeroka regulacja konstytucyjna w zakresie oświaty skłania ku stwierdzeniu,ież ustrojodawca przykładał do tych zagadnień bardzo dużą wagę. Taki wniosek interpretacyjny wzmacnia ponadto późniejsze orzecznictwo Trybunału Konstytucyjnego, który dostrzegał kapitalne znaczenie prawa do nauki, stwierdzając m.in., że: „prawo to musi być postrzegane zarówno w kategoriach dobra i wartości indywidualnej, jak i ważnego, podstawowego dobra społecznego. Urzeczywistnienie prawa do nauki jest nie tyle jakimś szczególnym przywilejem współczesnego człowieka, ile stanowi nieodzowny warunek rozwoju społeczeństwa i jednocześnie pełnego uczestnictwa jednostki w życiu społecznym” (wyrok TK z 8 listopada 2000 r., SK 18/99).

W art. 70 ust. 1 zdanie pierwsze Konstytucji RP przewidziano zatem prawo do nauki w tzw. wąskim ujęciu, zaś w pozostałych przepisach art. 70 - gwarancje 
tego prawa, a więc normy, które z jednej strony mają swoją własną unikalną treść i samodzielnie kształtują pozycję prawną jednostki w określonych obszarach, ale z drugiej strony pełnią też niejako funkcję służebną względem innej normy, jaką jest prawo do nauki. Do tych gwarancji należą: obowiązek nauki, obowiązek szkolny, zasada bezpłatności nauki w szkołach publicznych (z dopuszczalnymi wyjątkami w publicznych szkołach wyższych), wolność wyboru szkół innych niż publiczne, prawo zakładania szkół, zasada powszechnego i równego dostępu do wykształcenia oraz autonomia szkół wyższych (przy czym uznanie autonomii szkół wyższych za „gwarancję” konstytucyjnego prawa do nauki jest mocno dyskusyjne, brak tu bowiem bezpośredniego związku z prawem do nauki, który występuje w przypadku pozostałych gwarancji, a który w przypadku autonomii szkół wyższych jest związkiem jedynie pośrednim).

Zależność prawa do nauki w wąskim ujęciu i pozostałych przepisów art. 70 Konstytucji RP dostrzegł także Trybunał Konstytucyjny, który orzekł, że:

\begin{abstract}
„istnieje ścisły, nierozerwalny związek pomiędzy poszczególnymi gwarancjami konstytucyjnymi składającymi się na prawo do nauki. Oznacza to, że - zgodnie z postulatami prawidłowej wykładni, zakładającymi spójność i niesprzeczność regulacji - należy dążyć do poszukiwania takiego sensu postanowień konstytucyjnych wyrażających prawo do nauki, który pozwoli na wzajemne (niesprzeczne) uzgodnienie poszczególnych gwarancji ustanowionych w art. 70. Jeśli więc istota rozwiązań konstytucyjnych w art. 70 sprowadza się do najszerszego w sensie podmiotowym zagwarantowania prawa do nauki - to wszystkie inne postanowienia tego artykułu muszą być interpretowane w sposób, który w możliwie najpełniejszym zakresie urzeczywistniać będzie tę gwarancję konstytucyjną. Wszystkie dalsze ustępy art. 70 określają w konsekwencji narzędzia zapewniające realizację prawa do nauki. W tym sensie są one wtórne, instrumentalne w stosunku do podstawowej zasady wyrażonej w zdaniu pierwszym ustępu 1 art. 70” (wyrok TK z 8 listopada 2000 r., SK 18/99).
\end{abstract}

Każda z gwarancji prawa do nauki jest niezwykle istotna i rzeczywiście sprzyja pełnej realizacji prawa do nauki, jednakże z punktu widzenia diagnostyki edukacyjnej i prawnych skutków pomiaru dydaktycznego największe znaczenie ma tylko jedna z nich - przewidziana w art. 70 ust. 4 Konstytucji RP zasada równego dostępu do wykształcenia. Zanim jednak przejdę do omawiania relacji, jakie, w mojej ocenie, występują na tle zasady równego dostępu do wykształcenia pomiędzy diagnostyką (w szczególności pomiarem dydaktycznym) a normami 
prawa, ze względów operacjonalizacyjnych nieco uwagi wypada poświęcić tej właśnie konstytucyjnej zasadzie. Warto też spróbować ustalić jej treść na tyle, po pierewsze na ile jest to możliwe przy obecnym (ubogim) dorobku orzecznictwa i doktryny prawa oraz, po drugie, na ile (w jak szerokim zakresie) jest to potrzebne, mając na względzie tematykę niniejszego artykułu.

Najwięcej na temat zasady równego dostępu do wykształcenia możemy się dowiedzieć z orzecznictwa. Co oczywiste, najbardziej znaczący wpływ orzecznictwa konstytucyjnego na rozumienie zasady równości zaistniał w przypadku ogólnej zasady równości wobec prawa z art. 32 Konstytucji RP (zob. np. Safjan, Bosek, 2016). Pewne aspekty ogólnej zasady równości, o których szerzej za chwilę, można zatem przenosić odpowiednio na zasadę równego dostępu do wykształcenia. Natomiast w przypadku zasady równego dostępu do wykształcenia orzecznictwo jest już znacznie uboższe. Przykładowo Trybunał Konstytucyjny w sprawie dotyczącej tzw. „,amnestii maturalnej” stanął na stanowisku, że: „powszechność ta [o której mowa w art. 70 ust. 4 Konstytucji RP - przyp. ŁK] nie może być odczytywana w ten sposób, że każdy, niezależnie od umiejętności i posiadanej wiedzy (talentu), ma gwarantowany dostęp do każdego szczebla wykształcenia. Działania wyrównawcze podejmowane przez władze publiczne powinny dotyczyć przede wszystkim nierówności i barier faktycznych, w tym finansowych, a nie samych wyników edukacyjnych, które z założenia odzwierciedlają rzeczywisty zasób wiedzy i umiejętności danej osoby [...] Chodzi tu zatem o równość szans, a nie powszechny dostęp do efektów wykształcenia” (wyrok TK z 16 stycznia 2007 r., sygn. akt U 5/06). W innym orzeczeniu Trybunał Konstytucyjny stwierdził ponadto, że: „gwarancja równego dostępu do wykształcenia wyraża z jednej strony zakaz ustanawiania takich regulacji, które ograniczyłyby możliwość korzystania z tego wykształcenia przez określone grupy osób, z drugiej strony obliguje państwo do usuwania faktycznych barier i ograniczeń w korzystaniu z systemu edukacji publicznej" (postanowienie TK z 16 lutego 2000 r., sygn. akt TS 97/99).

Z kolei w przypadku dorobku literatury prawniczej w tym zakresie trzeba podkreślić, że równy dostęp do wykształcenia jest jednym z tych zagadnień z zakresu prawa oświatowego i prawa szkolnictwa wyższego, którego ranga jest odwrotnie proporcjonalna do stopnia zainteresowania nim przedstawicieli nauki. Olbrzymie znaczenie tej zasady dla pozycji faktycznej i prawnej ucznia i studenta nie idzie bowiem w parze z poświęcaniem jej należytej uwagi w nauce prawa, badaniu jej treści oraz sposobów konkretyzacji w aktach prawnych niższego rzędu. Poglądy doktryny w tym zakresie, zawarte w publikowanych artykułach i monografiach, a także w komentarzach do Konstytucji, są niezwykle pobieżne i - trzeba to 
powiedzieć - niewiele wnoszące. Trudno nie odnieść wrażenia, że często są także wzajemnie sprzeczne. Ich przytaczanie w niniejszym artykule nie przyniosłoby zatem jakiegokolwiek skutku poza takim, że Czytelnik stałby się bezpośrednim świadkiem ogromnych niedostatków i problemów, jakie w tym zakresie istnieją w nauce prawa.

Wobec braku jednoznacznego stanowiska doktryny prawa w tym zakresie, trzeba omawianą zasadę rozpatrywać niejako przez pryzmat ogólnej zasady równości wobec prawa (por. Kurzyna-Chmiel, 2013, s. 53-57). W tym zakresie dorobek doktryny prawa jest znaczny. Istotą zasady równości - w jej najbardziej ogólnym ujęciu - jest analogiczne traktowanie jednostek w analogicznych stanach faktycznych. Sprzeczne zatem - co do zasady - z zasadą równości jest identyczne traktowanie jednostek znajdujących się w różnych okolicznościach faktycznych oraz odmienne traktowanie jednostek w takich samych okolicznościach faktycznych. Ewentualne różnicowanie sytuacji prawnej jednostki może następować wyłącznie w oparciu o kryterium cechy relewantnej (Garlicki, 2016). To ona stanowi główny punkt ciężkości zasady równości. Z całą mocą należy zatem podkreślić, że równość nie oznacza formuły „każdemu to samo”; jest ona nie do spełnienia w systemach prawnych, a realizacja tak rozumianej równości prowadziłaby do niesprawiedliwości i nieuwzględniania cech różnicujących ludzi (Kurzyna-Chmiel, 2013, s. 53).

W związku z tym w sferze edukacji kryterium różnicowania sytuacji prawnej jednostek, w tym różnicowania dostępu do kolejnych etapów edukacyjnych, będą przede wszystkim indywidualne talenty i zdolności intelektualne lub dotychczasowe osiągnięcia edukacyjne, a czasami inne czynniki, jak np. niepełnosprawność. Pomiar tych talentów i zdolności (jakość, dokładność tego pomiaru) wpływa zatem bezpośrednio na pozycję prawną jednostki, w tym możliwość realizacji przez nią swych konstytucyjnych praw.

Zasada równego dostępu do wykształcenia z jednej strony stanowi więc pewne uzupełnienie ogólnej zasady równości wobec prawa, o której stanowi art. 32 Konstytucji, ale z drugiej strony została uznana przez ustrojodawcę za tak istotną, że wartą wyodrębnienia w oddzielnym przepisie. W przypadku omawianej zasady mamy jednak do czynienia z normą, która jest pochodną ogólnej zasady równości wobec prawa, ale niesie także swą własną treść. Z wyodrębnienia zasady równego dostępu do wykształcenia wynika bowiem okoliczność, przywoływana już w cytowanym wyżej orzecznictwie TK, że powszechność i równość dostępu do wykształcenia (a dokładniej - równość szans w zakresie takiego dostępu) ma być zapewniona nie tylko w sferze prawnej (gdyż to w tej sferze są nawiązywane i rozwiązywane stosunki pomiędzy jednostkami a administracyjnymi zakładami 
edukacyjnymi, jak szkoły i szkoły wyższe), ale także przez usuwanie „faktycznych" barier.

\section{ZASADA RÓWNEGO DOSTĘPU DO WYKSZTAŁCENIA A POMIAR DYDAKTYCZNY}

Cytowany wyżej pogląd Trybunału Konstytucyjnego oznacza zatem, że każdą procedurę rekrutacyjną, kwalifikacyjną czy egzaminacyjną dotyczącą edukacji jednostki, a zwłaszcza toku pokonywania poszczególnych etapów edukacyjnych i ubiegania się o dopuszczenie do kolejnych, należy rozpatrywać przez pryzmat zasady równego dostępu do wykształcenia, i to nie tylko w jej prawnym wymiarze. Owe „faktyczne” bariery, o których mowa wyżej, mogą bowiem mieć swe źródło także w uwarunkowaniach pozaprawnych, w tym z zakresu pomiaru dydaktycznego. Co oczywiste, w świetle poglądów TK, procedury te nie mają dawać każdej jednostce efektu w postaci jednakowej pozycji edukacyjnej, ale mają jej zapewniać równe szanse na każdym etapie edukacyjnym i, co najważniejsze z punktu widzenia niniejszego artykułu, w dostępie do każdego kolejnego etapu edukacyjnego. Mowa wszak o powszechnym i równym dostępie do wykształcenia, a nie powszechnym i równym wykształceniu.

W tym miejscu omawiana wyżej konstytucyjna zasada pokrywa się z zagadnieniami z zakresu diagnostyki edukacyjnej. Powiązania tego nie dostrzegano do tej pory w literaturze - tak pedagogicznej, jak i prawniczej. Rozważania naukowe dotyczące diagnostyki edukacyjnej postrzega się przede wszystkim z punktu widzenia nauk pedagogicznych. W diagnostyce upatruje się funkcji edukacyjnych, wychowawczych, ewaluacyjnych. O jej problemach również dyskutuje się zazwyczaj z punktu widzenia nauk pedagogicznych, a mówiąc jeszcze prościej - o diagnostyce edukacyjnej jako pewnej specyficznej części pedagogiki dyskutuje się w ramach edukacji i na rzecz edukacji, niekiedy łącząc tę dyscyplinę z innymi, jak np. wyodrębnianie diagnozy unormowanej, której podstawą jest psychometria, a pochodną psychometrii - pomiar dydaktyczny (Niemierko, 2009), badanie procesów egzaminacyjnych z punktu widzenia etyki (zob. np. Biuletyn Badawczy Centralnej Komisji Egzaminacyjnej, 6, 7, 2006) czy też rozpatrywanie edukacyjnych zmian i ich implementacji w kontekście ogromnej złożoności socjologicznej tego procesu (Szaleniec, 2001). Zupełnie incydentalnie łączono pomiar dydaktyczny z naukami prawnymi, nie formułując jednak w tym zakresie żadnych konkretnych wniosków badawczych, a postulując np. kodyfikację postępowania 
uczestników zewnętrznych egzaminów, przede wszystkim dla zabezpieczenia ich prawidłowego przebiegu (Groenwald, 2006).

W doktrynie prawa oświatowego i prawa szkolnictwa wyższego występuje podobny, sygnalizowany już wcześniej problem. W rozważaniach naukowych przeważa dogmatyczna analiza ustroju oświaty i szkolnictwa wyższego (który zawsze jest określany normami prawa), wzajemnych praw i obowiązków, jakie występują pomiędzy jednostką a władzą publiczną w stosunkach ze sfery edukacji oraz norm o charakterze proceduralnym, których celem jest urzeczywistnienie norm materialnoprawnych. W naukach prawnych nie dostrzega się szerszych związków tych norm z zagadnieniami nieleżącymi bezpośrednio w sferze prawa.

W obu powyższych sferach widoczne jest zatem „zamknięcie” się w omawianym w niniejszym artykule obszarze na zagadnieniach właściwych danej dziedzinie. Tymczasem w mojej ocenie rzeczywista równość w dostępie do wykształcenia (a właśnie taka - rzeczywista - ma ona być w świetle polskiej Konstytucji) nie daje się kompleksowo analizować bez jednoczesnego zestawienia zagadnień związanych z pomiarem dydaktycznym (mowa jest przecież o wykształceniu jako takim i o pokonywaniu kolejnych etapów edukacyjnych) oraz zagadnień prawnych (tu z kolei mowa przede wszystkim o bezwzględnie wiążącej normie prawnej i to normie rangi konstytucyjnej, jaką jest równy dostęp do wykształcenia).

W świetle omówionych wyżej konsekwencji, jakie konstytucyjna zasada równego dostępu do wykształcenia przynosi kształceniu wyższemu, szczególny nacisk dalszych rozważań warto położyć na kształcenie wyższe. O ile powszechne (i zwykle obowiązkowe) kształcenie do poziomu średniego staje się cywilizacyjnym standardem i prawnym obowiązkiem państw, o tyle w przypadku wykształcenia wyższego powszechnie przyjmuje się, że na państwie nie ciąży obowiązek zapewnienia go każdej jednostce, która będzie tego pożądać (co podkreślono także w przytaczanym wyżej orzecznictwie TK). Limitowanie dostępności edukacji w oparciu o stosowną cechę relewantną jest zresztą akceptowane również w orzecznictwie międzynarodowym, gdzie uzależnienie wstępu na studia od warunków intelektualnych kandydata uznaje się za zgodne z treścią prawa do nauki (Jakubowski, 2014). Postępowania rekrutacyjne w szkołach wyższych, a zwłaszcza na oblegane kierunki w najlepszych szkołach wyższych, mają więc charakter konkurencyjny.

Istotą takich postępowań, ich najważniejszym elementem, jest selekcja kandydatów w warunkach popytu przewyższającego podaż, a finalnie - władcze rozstrzygnięcie, po przeprowadzeniu postępowania określonego prawem, o przyjęciu lub odmowie przyjęcia na studia poszczególnych kandydatów. Jeżeli zatem w tym zakresie szeroko rozumiane państwo świadczy usługi edukacyjne na 
poziomie wyższym na rzecz jednostek, a więc wykonuje w tym zakresie pewną publicznoprawną działalność administracyjną, a ponadto w istotę świadczenia tych usług wpisane jest dopuszczenie do nich tylko wybranych jednostek, to wszystkie jednostki muszą dysponować równością szans w zakresie dostępu do tych usług i równość ta, jak już było to wspominane, ma mieć charakter materialny, faktyczny.

Instytucją prawną, a zarazem edukacyjną, która w świetle powyższych zagadnień wysuwa się na pierwszy plan, jest egzamin maturalny. W polskim systemie edukacji pełni on bardzo specyficzną rolę - tak z punktu edukacyjnego (diagnostycznego), jak i prawnego. Będąc standaryzowanym egzaminem zewnętrznym, przeprowadzanym w oparciu o osiągnięcia nauki w sferze diagnostyki edukacyjnej i przy pomocy wyspecjalizowanych narzędzi pomiarowych, z jednej (edukacyjnej) strony jest sprawdzeniem wiedzy i umiejętności nabytych przez jednostkę w toku kształcenia, zaś z drugiej (prawnej) strony jest ustawowym wymogiem podjęcia studiów, a ponadto w zdecydowanej większości przypadków jego wyniki są jedynym prawnym kryterium selekcji kandydatów na studia I stopnia oraz jednolite studia magisterskie ${ }^{2}$. Egzamin maturalny z prawnego punktu widzenia ma zatem znaczenie kolosalne - w większości przypadków jest jedynym w polskim porządku prawnym narzędziem, za pomocą którego jednostka może realizować przysługujące jej prawo do nauki na poziomie wyższym. Jest to swoisty pomost pomiędzy systemem oświaty i systemem szkolnictwa wyższego. Wyniki egzaminu maturalnego kandydatów na studia sklasyfikowane na jednej liście rekrutacyjnej stanowią więc $\mathrm{w}$ istocie przesądzający element materiału dowodowego w postępowaniu administracyjnym w przedmiocie przyjęcia kandydata na studia. Skoro zatem dostęp do studiów wyższych w większości przypadków został uzależniony wyłącznie od jednego kryterium, tj. wyniku egzaminu maturalnego, a wobec tego wynik ten jest narzędziem realizacji konstytucyjnego prawa do nauki na poziomie wyższym, to porównywalność wyników matur (w tym w skali wieloletniej), będąca pochodną zastosowanego pomiaru dydaktycznego, staje się warunkiem zaistnienia równego dostępu do wykształcenia.

Próba szerokiego opisania, jakie problemy są związane z porównywalnością wyników polskiego egzaminu maturalnego, stanowiłaby chyba faux pas. Problemy te są bowiem doskonale znane, a ponadto istnieje w tym zakresie dość pokaźna literatura. Bogate wnioski można także wyprowadzić z corocznych sprawozdań z egzaminu maturalnego publikowanych przez Centralną Komisję Egzaminacyjną.

2 Aczkolwiek rzetelność naukowa każe podkreślić, że w tym zakresie planuje się zmiany w postaci przywrócenia możliwości przeprowadzania egzaminów wstępnych na studia, których wynik miałby stanowić nie więcej niż 50\% punktów możliwych do uzyskania w procedurze rekrutacyjnej (zob. art. 70 ust. 4 projektu ustawy Prawo o szkolnictwie wyższym i nauce, 22 stycznia 2018 r.). 
Do tego dorobku nauk pedagogicznych wypada jednak dodać kilka spostrzeżeń prawnych. Otóż źródła - czasem znacznego - zachwiania porównywalności wyników egzaminów należy upatrywać nie tylko w niedoskonałości narzędzi pomiarowych, ale także w czynnikach ze sfery prawa. Wystarczy tu wymienić m.in. skrajną niestabilność przepisów regulujących procedury przeprowadzania egzaminów zewnętrznych, na co zresztą zwrócił uwagę również Rzecznik Praw Obywatelskich, odmienne stosowanie tych samych przepisów przez różne organy oświatowe czy też takie ukształtowanie przepisów prawa materialnego i procesowego, które wprawdzie zapewnia pozorną równość, ale w rzeczywistości wprost wyklucza pewne grupy jednostek z dostępu do wykształcenia wyższego bez ich winy i ze względu na kryterium prawnie irrelewantne (Kierznowski, 2016). Różnego rodzaju niedoskonałości regulacji prawnej z tego obszaru nie są zresztą problemem wyłącznie polskim (Camara, 1997).

Z punktu widzenia nauk pedagogicznych należy zatem mieć świadomość, że porównywalność wyników egzaminów zewnętrznych, na czele z egzaminem maturalnym (ze względu na jego funkcję), nie stanowi dobra o charakterze wyłącznie edukacyjnym, wychowawczym, diagnostycznym czy ewaluacyjnym, jak to się najczęściej postrzega. Porównywalność wyników egzaminów jest również dobrem o charakterze prawnym (dobrem chronionym prawem) i to, po pierwsze, dobrem rangi niezwykle wysokiej, bo wywodzonym z przepisu zawartego w akcie prawnym o najwyższej mocy obowiązującej oraz dotyczącym realizacji przez jednostkę jednego z jej fundamentalnych praw, zaś po drugie - nie dobrem abstrakcyjnym, ale namacalnym w takim sensie, że pozwalającym się zidentyfikować jako rozbieżność sfery bytu i sfery powinności, stanu istniejącego i postulowanego oraz - co za tym idzie - naruszenie normy konstytucyjnej w dającym się zidentyfikować zakresie. Potencjalne zachwiania porównywalności wyników pomiaru dydaktycznego, a nawet szerzej - potencjalnie niska, nieadekwatna do aktualnego stanu wiedzy naukowej jakość diagnostyki edukacyjnej w państwie przynosi zatem poważne reperkusje w sferze prawnej jednostki, m.in. w możliwości i zakresie korzystania przez tę jednostkę ze swych fundamentalnych praw, w tym przypadku z prawa do nauki oraz jednej z jego gwarancji, jaką jest zasada powszechnego i równego dostępu do wykształcenia. W sytuacji typowej zasada ta (wraz z prawem do nauki) zostaje zwyczajnie naruszona, zaś w sytuacji skrajnej, tzn. takiej, w której niedoskonałość (nietrafność) unormowanej diagnostyki edukacyjnej wpływa na kolejność, płynność lub w ogóle dopuszczalność podejmowania kolejnych etapów edukacyjnych, zasada ta (oraz prawo do nauki) doznaje nie tyle naruszenia, co zniweczenia. Prawny wymiar pomiaru dydaktycznego podkreśla się przecież choć zdaje się, że tylko pośrednio - także w literaturze pedagogicznej. Stwierdza 
się m.in., że błędy w konstrukcji tzw. egzaminów wysokiej stawki (high-stakes test), które obniżają trafność wyników tych egzaminów oraz mają psychometryczne konsekwencje dla ich analizy, prowadzą do nieadekwatności wniosków wyciąganych na podstawie tych wyników. Tym samym wyniki takie nie powinny być podstawą podejmowania decyzji, w szczególności dotyczących przechodzenia przez zdających do kolejnych etapów edukacyjnych (Skórska, Świst, Szaleniec, 2014).

Z perspektywy prawnej natomiast trzeba mieć na uwadze, że skoro konstytucyjna zasada powszechnego i równego dostępu do wykształcenia ma mieć charakter materialny, faktyczny, to owa równość i powszechność w dostępie do wykształcenia, a raczej jej realne zaistnienie, nierzadko będzie wykraczać dalece poza zagadnienia prawne. W takim przypadku ograniczanie się jedynie do dogmatycznych rozważań oscylujących wokół treści prawa materialnego i procesowego dotyczące dostępu do kolejnych etapów edukacyjnych jest pozbawione pewnej esencji - tego, co w rzeczywistości, w realnym stanie stosunków społecznych opartych na normach prawnych, decyduje o skuteczności tychże norm. Przykładem takiego zagadnienia, które w szalenie istotny sposób wpływa na realne zaistnienie tej zasady, jest właśnie jakość (oraz - z perspektywy innych zasad konstytucyjnych, przede wszystkim art. 2 Konstytucji - przewidywalność, nieretroaktywność, itd.) diagnostyki edukacyjnej w skali kraju. Czytelnik być może dostrzeże, jak łatwo wymienione wyżej zasady wywodzone $\mathrm{z}$ art. 2 Konstytucji RP i odnoszone do prawa (przede wszystkim do jego stanowienia) dają się wprost stosować do standardów pomiaru dydaktycznego. Nie da się w tym obszarze sprawnie poruszać w oderwaniu od nauk pedagogicznych.

Na marginesie należy oczywiście zaznaczyć, że występuje tu naturalna trudność w określeniu granicy naruszenia omawianej normy konstytucyjnej. Narzędzia pomiaru dydaktycznego z pewnością nigdy nie będą doskonałe - wszak nawet w literaturze podkreśla się, że przed przystąpieniem do nauki diagnostyki edukacyjnej i próby uchwycenia jej ducha trzeba mieć świadomość ograniczeń wszelkich metod diagnostycznych (Niemierko, 2009). Trudno jest zatem jednoznacznie ustalić, jak wysoce niedoskonałe mają one być, aby uznać, że już doszło do naruszenia konstytucyjnej zasady równego dostępu do wykształcenia, a jak małe mogą być niedoskonałości, aby w oparciu o inne zasady konstytucyjne, jak np. zasada proporcjonalności czy też ochrona praw nabytych i maksymalnie ukształtowanych ekspektatyw, uznać, że do naruszenia art. 70 ust. 4 Konstytucji RP nie doszło. Jednak to, co można w tym obszarze zrobić, to porównanie stosowanych w praktyce narzędzi pomiaru dydaktycznego oraz uwarunkowań okołopomiarowych z rzeczywistym stanem wiedzy naukowej w tym obszarze, tzn. z wypracowanymi 
w nauce - z założenia coraz bardziej doskonałymi, skoro nauka ma prowadzić do postępu - narzędziami pomiaru i warunkami jego przeprowadzania.

Gdy zatem występuje tutaj rozbieżność, tzn. organy władzy publicznej w sferze edukacji popełniają zaniechania w zakresie maksymalizacji jakości pomiaru dydaktycznego, tolerują istnienie efektu egzaminatora w egzaminach doniosłych (wysokiej stawki) i nie przeciwdziałają mu mimo istnienia takich możliwości uwiarygodnionych naukowo, nie ewaluują systemu pomiaru dydaktycznego w celu identyfikacji zaburzeń jego trafności i wyeliminowania ich w kolejnych latach itd. - wówczas należy stwierdzić, że państwo jako całość uchybia swym obowiązkom z art. 70 ust. 4 Konstytucji RP. Państwo nie „zapewnia” bowiem równego dostępu do wykształcenia, skoro istnieją sposoby pozwalające na minimalizację negatywnych zjawisk w obszarze pomiaru dydaktycznego (a „zmierzone” wiedza i umiejętności są - przypomnijmy - kryteriami prawnie relewantnymi w zakresie dostępu jednostek do edukacji), lecz państwo z nich nie korzysta, zadowalając się jedynie równością formalną. Analiza dorobku nauki w tej dziedzinie prowadzi do niepokojących - z perspektywy polskiej - wniosków, np. w kwestii wypracowywania mechanizmów zrównywania wyników z różnych sesji egzaminacyjnych w celu kontrolowania różnic w poziomie trudności różnych wersji testu. W porównaniu do pionierskich w zakresie nowoczesnych technik testowania Stanów Zjednoczonych, Polska wydaje się mieć co najmniej kilkudziesięcioletnie zaniedbania (Pokropek, Kondratek, 2012).

Przykładowo, w odwołaniu do wcześniejszego przykładu szkolnictwa wyższego, jeżeli nie istnieje nie tyle doskonała, co raczej możliwie zmaksymalizowana - w kontekście aktualnych osiągnięć nauki w tej sferze - porównywalność wyników egzaminu maturalnego, w tym w skali wieloletniej, to nie może być mowy o równym dostępie do wykształcenia wyższego w ujęciu materialnym, a co najwyżej - i to wątpliwie - w ujęciu formalnym. Wynika z tego również, że naruszenia doznaje samo prawo do nauki. Z tych względów diagnostyka edukacyjna, tak jak każda działalność państwa i jego organów, która skierowana jest do jednostki i determinuje, choćby pośrednio, jej pozycję prawną i faktyczną, nie może nie uwzględniać szerszego, w tym konstytucyjnego, „otoczenia prawnego”, w którym jest osadzona.

Opisane w niniejszym artykule zagadnienia to w istocie wierzchołek góry lodowej, jaką są relacje zachodzące pomiędzy prawem a elementami nauk pedagogicznych. Myli się ten, kto twierdzi, że występują one głównie na gruncie klasycznie pojmowanego prawa oświatowego i prawa szkolnictwa wyższego. W mojej ocenie istnieje potrzeba szerszych badań w tym zakresie, a nade wszystko jest to dowód na to, co w dyskursie naukowym podkreśla się w ostatnim czasie 
tak często i tak stanowczo - że sztywny podział na dyscypliny naukowe jest dysfunkcjonalny z punktu widzenia wyzwań, z jakimi mierzą się współczesne państwa i społeczeństwa. Jeżeli zatem Rzeczpospolita, stosownie do przepisów konstytucyjnych, chce zagwarantować swoim obywatelom rzeczywiście równy dostęp do wykształcenia, to zagadnieniom sygnalizowanym w niniejszym artykule z pewnością należy poświęcić więcej naukowej, interdyscyplinarnej uwagi, a wypracowane wnioski implementować w praktyce. Wszystko to zyskuje również na znaczeniu w aktualnych uwarunkowaniach, tzn. w obliczu ograniczania masowości kształcenia na większości kierunków studiów. Zwiększona konkurencyjność w dostępie do bezpłatnego szkolnictwa wyższego w znacznie większym niż dotychczas stopniu uzależnia sytuację prawną jednostki od jakości pomiaru, który został zastosowany wobec niej oraz jej konkurentów. Trafność zyskuje więc na (prawnym) znaczeniu, z czego można też wyprowadzić twierdzenie, że pomiar dydaktyczny daje się badać pod kątem legalności (na poziomie konstytucyjnym). Czy zatem posługiwanie się narzędziami pomiaru dydaktycznego w świetle zasady równego dostępu do wykształcenia, zwłaszcza wyższego, to jeszcze rozpoznawanie wyników uczenia się, czy już stosowanie norm prawnych, a może jedno i drugie?

\section{Bibliografia}

AERA, APA, NCME (2007). Standards for Educational and Psychological Testing. Gdańsk: Gdańskie Wydawnictwo Psychologiczne.

Babiuch, H. (2008). Konstytucyjny charakter i zakres ochrony prawa dziecka do nauki. Zeszyty Naukowe Państwowej Wyższej Szkoły Zawodowej im. Witelona w Legnicy, 4, s. 3-19.

Camara, W.J. (1997). Use and consequences of assessments in the USA: Professional, educational and legal issues. European Journal of Psychological Assessment, 13(2), s. $140-152$.

Czarny, P. (2009). Aksjologia systemu oświaty jako przedmiot regulacji konstytucyjnej (na przykładzie wybranych konstytucji europejskich). W: J. Wawrzyniak, M. Laskowska (red.), Instytucje prawa konstytucyjnego w dobie integracji europejskiej. Księga jubileuszowa dedykowana prof. Marii Kruk-Jarosz (s. 29-41). Warszawa: Wydawnictwo Sejmowe.

Garlicki, L. (2016). Polskie prawo konstytucyjne. Zarys wykładu. Warszawa: Wydawnictwo Wolters Kluwer.

Groenwald, M. (2006). Czy postępowanie uczestników zewnętrznych egzaminów powinno podlegać kodyfikacji? Egzamin. Biuletyn Badawczy, 7, s. 23-27.

Jakubowski, A. (2014). Prawo do nauki (art. 2 Protokołu nr 1 do Konwencji) a numerus clausus w szkolnictwie wyższym - uwagi na tle wyroku Europejskiego Trybunału Praw Człowieka z 2 kwietnia 2013 r. w sprawie Tarantino i inni przeciwko Włochom. Studia Prawa Publicznego, 1(5), s. 107-124. 
Jarosz-Żukowska, S., Żukowski, Ł. (2014). Prawo do nauki i jego gwarancje. W: M. Jabłoński (red.), Realizacja i ochrona konstytucyjnych wolności i praw jednostki w polskim porządku prawnym (s. 631-658). Wrocław: E-Wydawnictwo. Prawnicza i Ekonomiczna Biblioteka Cyfrowa. Wydział Prawa, Administracji i Ekonomii Uniwersytetu Wrocławskiego.

Kierznowski, Ł. (2016). Egzamin maturalny w Polsce. Analiza prawna. Białystok: Wydawnictwo Prawo i Partnerstwo.

Kierznowski, Ł. (2017), Prawo do nauki w aktach prawa międzynarodowego W: M. Perkowski, W. Zoń (red.), Umiędzynarodowienie krajowego obrotu prawnego. Tom I (s. 61-76). Białystok: Wydawnictwo Prawo i Partnerstwo.

Kolen, M.J., Brennar, R.L. (2014). Test equating, scaling and linking. Methods and practices. New York: Springer-Verlag.

Kozak, M. (2013). Prawo dziecka do edukacji. Założenia pedagogiczno-prawne i bariery realizacyjne, Warszawa: Biuro Rzecznika Praw Dziecka.

Kurzyna-Chmiel, D. (2012). Z rozważań nad jakością w oświacie. W: D.R. Kijowski, A. Miruć, A. Suławko-Karetko (red.), Jakość prawa administracyjnego (s. 471-491). Warszawa: Wydawnictwo Wolters Kluwer.

Kurzyna-Chmiel, D. (2013). Oświata jako zadanie publiczne. Warszawa: Wydawnictwo Wolters Kluwer.

Niemierko, B. (red.) (1994). Diagnostyka edukacyjna. Materiały z konferencji naukowej, która odbyła się w Instytucie Pedagogiki Uniwersytetu Gdańskiego oraz w Centrum Edukacji Nauczycieli w Gdańsku 25 i 26 czerwca 1993 roku. Gdańsk: Wydawnictwo Uniwersytetu Gdańskiego.

Niemierko, B. (2009). Diagnostyka edukacyjna. Warszawa: Wydawnictwo Naukowe PWN.

Niemierko, B. (2003). Jaki pomiar dydaktyczny jest nam potrzebny? W: B. Niemierko (red.), Trafność pomiaru jako podstawa obiektywizacji egzaminów szkolnych. Łódź: Wydawnictwo Wyższej Szkoły Humanistyczno-Ekonomicznej w Łodzi.

Niemierko, B., Szmigel, M.K. (2009). Badania międzynarodowe i wzory zagraniczne w diagnostyce edukacyjnej. Kraków: Grupa Tomami.

Phillips, S.E., Camara, W.J. (2006). Legal and ethical issues. W: R. Brennar (red.), Educational Measurement ( $4^{\text {th }}$ ed.), (s. 734-755). Westport: ACE/Praeger Series on Higher Education.

Pierzchała, J. (2016). Prawo oświaty prywatnej. Warszawa: Wydawnictwo Wolters Kluwer.

Pokropek, A., Kondratek, B. (2012). Zrównywanie wyników testowania. Definicje i przykłady zastosowania. Edukacja, 4(120), s. 52-71.

Safjan, M., Bosek, L. (red.) (2016). Konstytucja RP. Komentarz, tom I, Warszawa: Wydawnictwo C.H. Beck.

Skotnicki, K. (1995). Gwarancje prawa do nauki w projektach konstytucji. „Ruch Prawniczy, Ekonomiczny i Socjologiczny”, 2, s. 139-146.

Skórska, P., Świst, K., Szaleniec, H. (2014). Konsekwencje błędnego określenia rodzaju zadania testowego. Edukacja, 2(127), s. 67-84.

Szaleniec, H., Kondratek, B., Kulon, F., Pokropek, A., Skórska, P., Świst, K., Wołodźko, T., Żółtak, M. (2015). Porównywalne wyniki egzaminacyjne. Warszawa: Instytut Badań Edukacyjnych. 
Szaleniec, H. (2001). Próbny egzamin zewnętrznego systemu oceniania. W: B. Niemierko, W. Małecki (red.), Dawne i nowe formy egzaminowania. Wrocław: Wydawnictwo Dolnośląskiej Szkoły Wyższej Edukacji.

Woźniak, M. (red.) (2013). Administracja dóbr i usług publicznych. Warszawa: Wydawnictwo Difin.

Żółtak, M. (2015). Porównywalne wyniki egzaminacyjne. Warszawa: Instytut Badań Edukacyjnych. 